\title{
A Quantitative Assay for a Clara Cell-Specific Protein and Its Application in the Study of Development of Pulmonary Airways in the Rat
}

\author{
GURMUKH SINGH, SIKANDAR L. KATYAL, AND MARI-LOU WONG-CHONG \\ Department of Pathology, University of Pittsburgh School of Medicine and the Veterans Administration Medical \\ Center, Pittsburgh, Pennsylvania 15240
}

\begin{abstract}
Rat lung lavage contains a $10 \mathrm{kDa}$ protein that has been shown by immunocytochemistry to be specific for Clara cells. An inhibition enzyme-linked immunosorbent assay was established for this protein using rabbit antibody to the $10 \mathrm{kDa}$ Clara cell protein. The assay has a sensitivity of about $3.0 \mathrm{ng} / \mathrm{ml}$ and a working range of about 5 to $50 \mathrm{ng} / \mathrm{ml}$. Quantitation of the $10 \mathrm{kDa}$ protein in amniotic fluid revealed an increase of about 4-fold at day 20 of gestation. The $10 \mathrm{kDa}$ protein content of lung homogenate increased steadily from day 18 of gestation to 1 wk after birth, after which a decline was observed. Nearly 60 -fold increase in the concentration of the $10 \mathrm{kDa}$ Clara cell protein in lungs was noted from day 18 of gestation to birth and a further about 7-fold increase was noted from the day of birth to 1 wk of age. A progressive increase in the $10 \mathrm{kDa}$ protein, with increasing age, was also noted on immunoblot analysis of lung homogenates. As judged from the immunoblots of lung homogenates, stained with rabbit antirat $10 \mathrm{kDa}$ protein antiserum, the content of an antigenically similar $200 \mathrm{kDa}$ Clara cell protein was negligible. The quantitative results for $10 \mathrm{kDa}$ Clara cell protein parallel the results of immunocytochemistry and quantitation of the volume density of Clara cell granules indicating that quantitation for the $10 \mathrm{kDa}$ protein could be used to monitor the development of Clara cells and that of the pulmonary airways. (Pediatr Res 20: 802-805, 1986)
\end{abstract}

\section{Abbreviations}

ELISA, enzyme-linked immunosorbent assay SDS, sodium dodecyl sulfate

Studies of pulmonary development have dealt mainly with the alveolar part of the lung and surfactant (1-4). Examination of airway cells has been limited to morphologic studies $(5,6)$. Studies of pulmonary surfactant have led to the development of clinical tests useful for assessing pulmonary maturity of the fetus in utero (7-9). In particular, an assay for surfactant apoprotein appears to be promising in accurate determination of the development of the surfactant system (9).

Pulmonary airway epithelium consists of ciliated and secretory cells (10). Nonmucous type of secretory cells, i.e. Clara cells, are the dominant cell type in the distal airways, particularly in rodents $(11,12)$. We have previously shown that two of the

Received February 3, 1986; accepted April 7, 1986.

Address for correspondence and reprints Dr. Gurmukh Singh, Chief, Laboratory Service (113), V.A. Medical Center, Pittsburgh, PA 15240.

This investigation was supported by PHS Grants CA 33717 and HL 28193, the Veterans Administration, and the American Diabetes Association. proteins in lung lavage fluid are specific to Clara cells and serve as markers for these cells in fetal and adult lungs (13-15). One of these proteins (protein $\mathrm{C}$ ) has been isolated to purity and shown to have a molecular weight of about 10,000 . So far the only way to quantitatively study the development of the airways has been to conduct a morphometric analysis (6). We have now established a quantitative assay for the Clara cell $10 \mathrm{kDa}$ protein (protein C) to study the development of pulmonary airways.

\section{METHODS}

Animals. Pregnant Sprague-Dawley albino rats of known duration of gestation were purchased from Zivic Miller, Allison Park, PA. The animals were sacrificed by intraperitoneal injection of pentobarbital sodium and the pups were delivered by cesarean section. Amniotic fluid was collected from each sac by aspiration. Fluid from sacs in each horn of the uterus was pooled. Lungs from the pups were also pooled accordingly, weighed, and stored at $-40^{\circ} \mathrm{C}$ until further use. The number of fetuses in each horn varied from four to nine. The pups sacrificed on the day of birth were labeled as newborn day 0 and the pups sacrificed on the day after birth were designated as day 1 animals. For day 0 , 1 , and 2 animals, lungs from four to five pups were pooled and stored frozen. At day 4 and in older animals lungs from each animal were processed separately.

Preparation of lung homogenate. Lungs were dissected free of trachea and extra pulmonary bronchi, and were homogenized in cold saline with a Brinkman Polytron to obtain a suspension containing $1.0 \mathrm{~g}$ lung tissue per $10 \mathrm{ml}$ of saline. The homogenates were centrifuged at $18,000 \times g$ for $30 \mathrm{~min}$ and the supernatants were aliquoted and stored frozen at $-40^{\circ} \mathrm{C}$ until further use.

Isolation of the $10 \mathrm{kDa}$ Clara cell protein. The detailed method for isolation is being reported elsewhere (Singh G, Singal S, Katyal SL, Brown WE, Gottron SA, unpublished data). Briefly, surfactant in lung lavage was sedimented by centrifugation at $18,000 \times g$ for $30 \mathrm{~min}$ and the supernatant concentrated by micropore membrane filtration (Amicon YM 5 membrane). The concentrated lavage was fractionated by molecular sieving on AcA 54 gel (LKB) and the fractions monitored by immunoblotting using antirat Clara cell antiserum (15). The fractions containing the $10 \mathrm{kDa}$ protein were pooled, dialyzed in $0.01 \mathrm{M}$ Tris, pH 8.0, and applied to a Mono Q column (Pharmacia Inc., Piscataway, NJ). The proteins bound to the column were eluted with a linear gradient of $1.0 \mathrm{M} \mathrm{NaCl}$ in $0.02 \mathrm{M}$ Tris $\mathrm{pH} 8.0$. The $10 \mathrm{kDa}$ protein eluted in the fractions containing 0.23 to $0.32 \mathrm{M}$ $\mathrm{NaCl}$. (The fractions were monitored by immunoblotting.) The fractions containing the $10 \mathrm{kDa}$ protein were pooled and dialyzed in $0.025 \mathrm{M}$ Bis-Tris pH 7.0 and applied to a Mono P column (Pharmacia). The proteins bound to the column were eluted with Polybuffer 74, $\mathrm{pH} 3.8$. The three isotypes of the $10 \mathrm{kDa}$ protein eluted at $\mathrm{pH} \mathrm{4.7,4.4,} \mathrm{and} \mathrm{4.1.} \mathrm{The} \mathrm{separated} \mathrm{isotypes} \mathrm{were}$ 
further applied to Pro-RPC column (Pharmacia) and eluted with a linear gradient of acetonitrile containing $0.1 \%$ trifluoroacetic acid. The purity of the final preparation was tested by silver staining of SDS polyacrylamide gels. A pool of three isotypes of the $10 \mathrm{kDa}$ protein was used as standard as well as for coating the ELISA plates.

Preparation of antiserum specific to the $10 \mathrm{kDa}$ Clara cell protein. The methods for preparation of the antiserum and characterization of the antiserum have been published earlier $(13,15)$. Briefly, female New Zealand white rabbits were immunized with separated $10 \mathrm{kDa}$ protein. The resulting antiserum was absorbed with rat serum and rat liver homogenate. The absorbed antiserum was tested for its specificity by immunohistochemistry and immunoblotting (15).

Inhibition ELISA. Total protein in the purified preparation of $10 \mathrm{kDa}$ Clara cell protein was determined by the Bradford assay using bovine serum albumin as the standard (16). The purified preparation of $10 \mathrm{kDa}$ protein was used as the source of pure antigen and as the reference standard. The procedure for the assay is depicted in Table 1. Microtiter plate wells were coated with $10 \mathrm{ng}$ of pure $10 \mathrm{kDa}$ protein by filling the wells with 200 $\mu \mathrm{l}$ of the antigen solution containing $10 \mathrm{ng}$ protein and by drying the plates at $37^{\circ} \mathrm{C}$. The dried wells were washed with barbital buffer $[0.05 \mathrm{M}$, pH 8.6 containing $0.05 \%(\mathrm{v} / \mathrm{v})$ Tween 20]. Additional protein binding sites on the wells were blocked by addition of $250 \mu 1$ of $5 \%(\mathrm{w} / \mathrm{v})$ bovine serum albumin in barbital buffer and by incubating at room temperature for $1 \mathrm{~h}$. The plates were washed three times with barbital buffer and $200 \mu$ l of the antibody (or a mixture of the antibody and antigen) were added to the wells. For positive control, rabbit antirat Clara $10 \mathrm{kDa}$ protein antibody at a dilution of 1:400 was used. For negative controls, the antibody was omitted entirely. To obtain the standard curve $100 \mu \mathrm{l}$ of varying concentrations of $10 \mathrm{kDa}$ Clara cell antigen $(1.56$ to $100 \mathrm{ng} / \mathrm{ml})$ were incubated overnight with the antibody ( $100 \mu \mathrm{l}$ antibody at $1: 200$ dilution) at $4^{\circ} \mathrm{C}$ and used in lieu of the antibody. Test specimens at appropriate dilutions replaced the standard antigen in other wells. The dilution of the test specimens was increased until the concentration of the Clara cell $10 \mathrm{kDa}$ protein was in the linear region of the standard curve.

The incubation with antibody (or antibody antigen mixture) was carried out at room temperature for $90 \mathrm{~min}$. The plates were washed three times with barbital buffer and $200 \mu \mathrm{l}$ of 1:200 dilution of peroxidase conjugated swine antirabbit $\operatorname{IgG}$ was added to the wells and incubated at room temperature for $2.5 \mathrm{~h}$. The plates were washed three times with barbital buffer and peroxidase reaction was developed with $o$-phenylenediamine by incubating with $100 \mu$ l of the dye at a concentration of $1.0 \mathrm{mg} / \mathrm{ml}$ in

\section{Table 1. Inhibition ELISA}

1. Coat microtiter plate wells with pure $10 \mathrm{kDa}$ Clara cell protein.

2. Wash with barbital buffer three times.

3. Block residual protein binding sites with $5 \%$ bovine serum albumin.

4. Wash with barbital buffer three times.

5. Incubate, overnight at $4^{\circ} \mathrm{C}, 100 \mu \mathrm{l}$ of $1: 200$ rabbit antirat Clara 10 $\mathrm{kDa}$ antibody with equal volume of:

(a) known amount of pure $10 \mathrm{kDa}$ Clara cell protein, in doubling dilutions, starting at $100 \mathrm{ng} / \mathrm{ml}$.

(b) barbital buffer (positive control for antibody)

(c) barbital buffer without antibody (control for background)

(d) unknown specimen at an appropriate dilution

6. Add solution from step 5 to blocked and washed wells (from step 4) and incubate for $90 \mathrm{~min}$ at room temperature.

7. Wash with barbital buffer three times.

8. Add $200 \mu \mathrm{l}$ of $1: 200$ dilution of peroxidase conjugated swine antirabbit IgG for $2.5 \mathrm{~h}$ at room temperature.

9. Wash with barbital buffer three times.

10. Develop peroxidase enzyme color reaction.

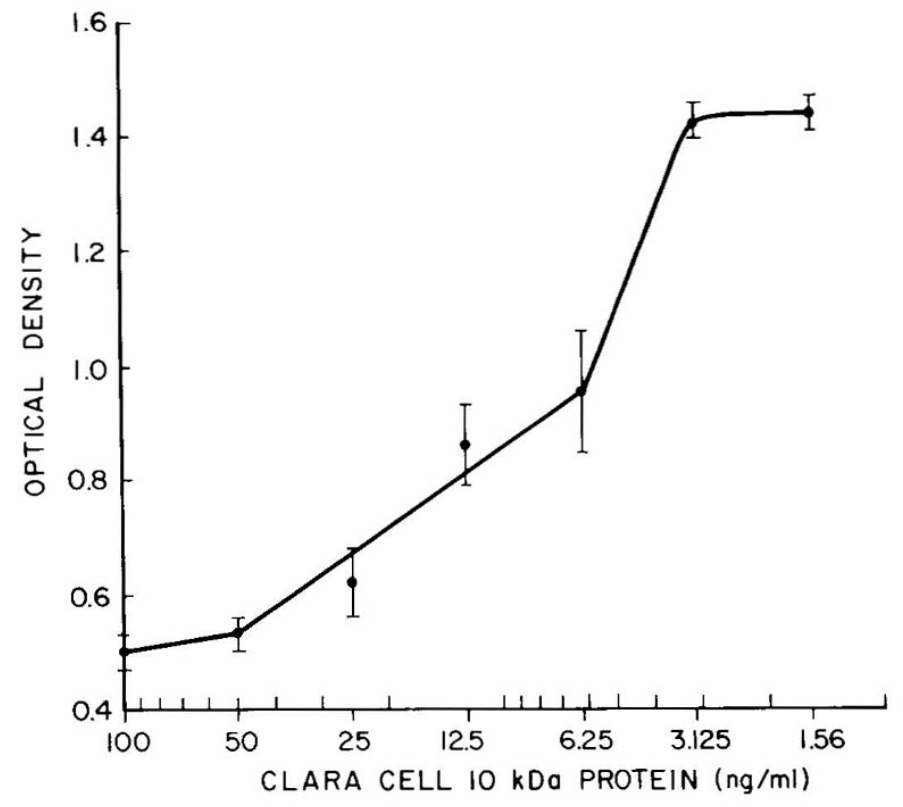

Fig. 1. Standard curve for quantitation of Clara cell $\mathrm{kDa}$ protein. The ordinate shows concentration of the pure $10 \mathrm{kDa}$ protein in log scale. The abscissa depicts the optical density readings in linear scale. The optical density results show the mean and SD of the readings. The curve is nearly linear in the 6.25 to $50 \mathrm{ng} / \mathrm{ml}$ of the $10 \mathrm{kDa}$ protein concentration range.

water containing $0.03 \%$ hydrogen peroxide. The plates were incubated at $37^{\circ} \mathrm{C}$ for $45 \mathrm{~min}$ and the enzyme reaction was terminated by adding $50 \mu \mathrm{l}$ of $9 \mathrm{~N}$ sulfuric acid. The optical density of the reaction mixture was monitored on a Dynatech ELISA reader at a wave length of $450 \mathrm{~nm}$. The optical density in the wells containing known amounts of antigen in the antigen antibody mixture was plotted against the antigen concentration to obtain the standard curve and the concentration of $10 \mathrm{kDa}$ protein in test samples were determined by interpolation. The results of Clara cell protein concentration were compared between successive age groups by Student's $t$ test and the $p$ values are reported.

Immunoblot analysis. One specimen of lung homogenate from each age group (gestational day 18 to postnatal day 14 and adult) was analysed by immunoblotting using rabbit antirat $10 \mathrm{kDa}$ antiserum (15). Total protein in each specimen was adjusted to $1.0 \mathrm{mg} / \mathrm{ml}$ by diluting with SDS-sample buffer. The specimens were subjected to SDS-polyacrylamide gel electrophoresis in gradient gels containing 7.5 to $15 \%$ acrylamide. The electrophoresed proteins were transferred to nitrocellulose paper and the paper stained by the immunoperoxidase method with rabbit antirat $10 \mathrm{kDa}$ antiserum. Rat lung lavage was included in the immunoblotting run as a control.

\section{RESULTS}

The data on the characterization of the rabbit antirat Clara cell $10 \mathrm{kDa}$ protein antiserum have been presented earlier (1315). Briefly, the antiserum specifically stains Clara cells in the pulmonary airways by immunohistochemistry and reacts with the three isotypes of the $10 \mathrm{kDa}$ protein. The antiserum also reacts with a larger, approximately $200 \mathrm{kDa}$ (protein A) protein that has been shown to be antigenically similar to the $10 \mathrm{kDa}$ protein (protein C) (15).

The optimum amount of $10 \mathrm{kDa}$ protein to be used for coating the wells and the dilution of antiserum used in the assay were determined by a checkerboard titration. Ten ng of the antigen per well and 1:400 final dilution of the antiserum were the lowest amounts of antigen and antibody, respectively, giving the highest 
optical density reading. A progressive decrease in the optical density reading was noted with reduction in the amount of antigen used to coat the plates or reduction in the concentration of the antiserum.

The results of standard curve construction are depicted in Figure 1. With the addition of known amounts of free pure antigen to the antibody, progressive decrease in the optical density reading was noted in the range of $1.5 \mathrm{ng} / \mathrm{ml}$ of the antigen to $100 \mathrm{ng} / \mathrm{ml}$ of the antigen. The curve was nearly linear in the range of 6.25 to $50 \mathrm{ng} / \mathrm{ml}$ of Clara cell $10 \mathrm{kDa}$ antigen.

$10 \mathrm{kDa}$ Clara cell protein content of amniotic fluid. The Clara cell $10 \mathrm{kDa}$ protein was detectable in the amniotic fluid from day 18 fetuses, however, little change was noted over the next day. At day 20, a 3.8-fold increase in the concentration of the 10 $\mathrm{kDa}$ protein was noted with a smaller increase over the next day (Table 2).

$10 \mathrm{kDa}$ protein concentration in lung homogenates. A progressive increase in the $10 \mathrm{kDa}$ Clara cell protein was apparent from day 18 of gestation to 1 wk after birth (Table 3). The most marked increase occurred around the time of birth to $1 \mathrm{wk}$ of age. Thereafter, a decrease in the relative content of the $10 \mathrm{kDa}$ Clara cell protein in the lung was observed. The concentration of $10 \mathrm{kDa}$ Clara cell protein in adult lungs was about $140 \mu \mathrm{g} / \mathrm{g}$ lung (wet weight).

Immunoblot analysis. As described earlier, rat lavage exhibited reactive bands in the molecular weight regions of 200 and 10 $\mathrm{kDa}(5)$. The $10 \mathrm{kDa}$ protein was clearly detectable in the lung homogenate of gestational day 20 rats, the staining in the specimens from younger animals was equivocal. There was a progressive increase in the staining intensity for $10 \mathrm{kDa}$ protein with increasing age. The $200 \mathrm{kDa}$ protein was not detectable in the rat lung homogenate specimens, including that from adult rat.

\section{DISCUSSION}

The quantitative assay was established using purified $10 \mathrm{kDa}$ Clara cell protein as the standard. Lung lavage contains a larger

Table 2. Concentration of $10 \mathrm{kDa}$ Clara cell protein in Amniotic fluid*

\begin{tabular}{cc}
\hline Day of gestation & $10 \mathrm{kDa}$ Concentration \\
\hline 18 & $49.7 \pm 0.9$ \\
19 & $47.8 \pm 2.1 \dagger$ \\
20 & $186 \pm 11.9 \dagger$ \\
21 & $198 \pm 12.6$
\end{tabular}

* The figures given are the mean \pm SD deviation of the concentration in $\mathrm{ng} / \mathrm{ml}$. Four pools of amniotic fluids, from four to nine fetuses/pool were assayed at each age group.

† The difference in the $10 \mathrm{kDa}$ protein concentration of amniotic fluid between days 19 and 20 is significant $(p<0.001)$. (about $200 \mathrm{kDa}$, Clara cell protein A) protein antigenically similar to the $10 \mathrm{kDa}$ protein (15). Earlier studies with antibodies eluted from the 10 and $200 \mathrm{kDa}$ proteins had shown that the two proteins are antigenically nearly identical (15). Preliminary results of in vitro translation of rat lung mRNA and immunoprecipitation of the nascent labelled proteins followed by SDS polyacrylamide gel electrophoresis and autoradiography suggest that the $10 \mathrm{kDa}$ protein is the primary translation product since the $200 \mathrm{kDa}$ protein was not detectable (Singh G, Katyal SL, unpublished observation). The immunoblotting results of lung homogenates indicate that the $200 \mathrm{kDa}$ protein content of the specimens examined is probably negligible. Even if trace amount of $200 \mathrm{kDa}$ protein were present in the lung homogenates, as was most likely the case, the results of ELISA for $10 \mathrm{kDa}$ protein do provide a comparison of the $10 \mathrm{kDa}$ antigen content (i.e. the sum of antigenic moieties on the $10 \mathrm{kDa}$ and $200 \mathrm{kDa}$ Clara cell proteins) at different phases in the development of the lung. The quantitative results of increase in $10 \mathrm{kDa}$ protein content of the lung, with increasing age, were corroborated by the findings of immunoblot analysis.

The increases in the amniotic fluid and lung homogenate concentration of the $10 \mathrm{kDa}$ Clara cell protein parallel the changes seen in surfactant and surfactant apoprotein $(4,17)$. Significant levels of surfactant apoprotein and Clara cell protein are seen in amniotic fluids at day 19 of gestation with marked increase by day 20 and little change on day 21 (4). The lack of increase from day 20 to 21 may be related to the changes in the amniotic fluid during that period. A marked reduction in the volume of amniotic fluid was noted between the 20th and 21 st days of gestation. Even more noticeable than the reduction in the volume of the fluid is the change in the physical characteristics of the specimens. The fluid is markedly mucoid at day 21 . The lack of increase in the Clara cell protein content is remarkably similar to the data on quantitation of surfactant apoprotein (4). The failure to observe an increase in the Clara cell protein and surfactant apoprotein content is probably spurious (similar to the spurious hyponatremia in a lipemic serum).

The progressive increase in the concentration of the Clara cell $10 \mathrm{kDa}$ protein, in lung homogenate, also parallels the increase in surfactant apoprotein (4). The increase in the $10 \mathrm{kDa}$ protein is also consistent with the reported increase in the volume density of secretory granules in Clara cells (6). Massaro et al. (6) have reported a progressive increase in the volume density of Clara cell granules from birth to $1 \mathrm{wk}$ of age and a decline in the volume density of secretory granules after $2 \mathrm{wk}$ of age. The same authors reported a second increase in the adult animals. The initial peak of Clara cells secretory granule volume density and the quantitative results of the $10 \mathrm{kDa}$ protein concentration at 1 wk of age are quite comparable. A second rise seen in the volume density of Clara cell granules in adults does not have its counterpart in the results of concentration of $10 \mathrm{kDa}$ protein in lung

Table 3. Concentration of $10 \mathrm{kDa}$ Clara cell protein in homogenates of whole lungs*

\begin{tabular}{lrcr}
\hline \multicolumn{1}{c}{ Age of Animals } & & $\begin{array}{c}\text { Concentration of 10 kDa protein in } \\
\mu \mathrm{g} / \mathrm{g} \text { wet lung wt (mean } \pm \text { SD) }\end{array}$ & $p$ value \\
\hline Gestational day & $18(n=3)$ & $0.55 \pm 0.45$ & $<0.01$ \\
& $19(n=4)$ & $2.56 \pm 0.66$ & $<0.001$ \\
Day of birth (day 0) & $20(n=4)$ & $10.6 \pm 0.86$ & $<0.001$ \\
Postnatal day & $21(n=4)$ & $17.0 \pm 1.71$ & $<0.001$ \\
& $1(n=4)$ & $31.8 \pm 3.7$ & NS \\
& $2(n=4)$ & $33.5 \pm 1.7$ & $<0.01$ \\
Adult & $4(n=3)$ & $15.3 \pm 14.7$ & $<0.01$ \\
& $7(n=4)$ & $232.4 \pm 45.5$ & $<0.02$ \\
& $14(n=4)$ & $122.2 \pm 13.7$ & $<0.01$ \\
& $(n=3)$ & $139.9 \pm 32.1$ & NS \\
\hline
\end{tabular}

\footnotetext{
* Lung tissues were pooled from four to nine fetuses from the same litter. In newborn animals up to 2 days of age, lungs from four to five pups were pooled. Lungs from animals 4 days old and older were assayed individually. The number of pools or animals is given in parenthesis in the first column. The last column shows the $p$ value of differences between the adjacent groups.
} 
homogenate. This disparity is in all likelihood due to the lower relative Clara cell mass as compared to the total lung mass in adults than in 1-wk-old animals.

Immunocytochemistry studies of developing lung, reported earlier, had shown that the adult pattern of staining of Clara cell proteins was apparent at $2 \mathrm{wk}$ of age, the same age at which concentration of the $10 \mathrm{kDa}$ protein in lung homogenates reaches the adult levels (13).

Monitoring surfactant and surfactant apoprotein in amniotic fluids has proven to be a reliable assay for assessing pulmonary maturity of the fetus $(8,9)$. Markers for airway cells could be used in the same vein, however, teleologically surfactant and surfactant apoprotein assays would have an advantage as means of testing pulmonary maturity. In diabetic pregnancies, a disparity has been observed in the results of amniotic fluid content of surfactant lipids and surfactant apoprotein (9). Whether this discordance is a peculiarity of the surfactant apoproteins or a general phenomenon affecting other secretory proteins of the lung could be tested by analyzing the Clara cell proteins in amniotic fluids from diabetic mothers.

Acknowledgment. The authors thank Ms. Pat Turkovich for typing the manuscript.

\section{REFERENCES}

1. Williams M 1977 Development of the alveolar structure in the fetal rat in late gestation. Fed Proc 36:2653-2659

2. Clements JA, Tooley WH 1977 Kinetics of surface active material in the fetal lung. In: Hodson WA, (ed) Development of the Lung. Marcell Dekker, New York, pp 356-366

3. King RJ 1974 The surfactant system of the lung. Fed Proc $33: 2238-2247$
4. Katyal SL, Singh G 1983 An enzyme-linked immunoassay of the surfactant apoproteins. Its application to the study of fetal lung development in the rat. Pediatr Res 17:439-443

5. McDowell EM, Newkirk C, Coleman B 1985 Development of hamster tracheal epithelium: I. a quantitative morphologic study in the fetus. Anat Rec 213:429-447

6. Massaro GD, Davis L, Massaro D 1984 Postnatal development of the bronchiolar Clara cells in rats. Am J Physiol (Cell Physiol) 247:C197-C203

7. Mueller-Heubach E, Caritis SM, Edelstone DI, Turner JH 1978 Lecithin/ sphnigomeyelin ratio in amniotic fluid and its value for the prediction of neonatal respiratory distress syndrome in pregnant diabetic women. Am J Obstet Gyncol 130:28-34

8. Amenta JS, Silverman JA 1983 Amniotic fluid lecithin, phosphatidylglycerol, $\mathrm{L} / \mathrm{S}$ ratio and foam stability tests in predicting respiratory distress in the newborn. Am J Clin Pathol 79:52-64

9. Katyal SL, Amenta JS, Singh G, Silverman JA 1984 Deficient lung surfactant apoprotein in amniotic fluid with mature phospholipid profile from diabetic pregnancy. Am J Obstet Gynecol 148:48-53

10. Reid L, Jones R 1979 Bronchial mucosal cells. Fed Proc 38:191-196

11. Kuhn C, Calloway LA, Askin FB 1974 The formation of granules in the bronchiolar Clara cell of the rat I. Electron microscopy. J Ultrastruct Res 49:387-400

12. Massaro GD, Paris M, Thet LA 1979 In vivo regulation of secretion of bronchiolar Clara cell in rats. J Clin Invest 63:167-172

13. Singh G, Katyal SL 1984 An immunologic study of the secretory products of rat Clara cells. J Histochem Cytochem 32:49-54

14. Singh G, Katyal SL, Ward JM, Gottron SA, Wong-Chong ML, Riley EJ 1985 Secretory proteins of the lung in rodents: Immunocytochemistry. J Histochem Cytochem 33:564-568

15. Singh, G, Katyal SL, Gottron SA 1985 Antigenic, molecular and functional heterogeneity of Clara cell secretory proteins in the rat. Biochim Biophys Acta 829:156-163

16. Bradford M $1976 \mathrm{~A}$ rapid and sensitive method for the quantitation of microgram quantities of protein utilizing the principle of protein-dye binding. Anal Biochem 72:248-254

17. Katyal SL, Estes LW, Lombardi B 1977 Method for the isolation of surfactant from homogenates and lavages of lung of adult new born and fetal rats. Lab Invest 36:585-592 